\title{
Paikkakunnallisen asunnontarpeen selvitys tilastollisena tehtävänä
}

\author{
Kirjoittanut Aarno Strömmer.
}

\section{Johdanto.}

Kulkulaitosten ja yleisten töiden ministeriön alainen asuntotutkimustoimikunta myönsi kevaaällä 1952 Väestöpoliittiselle tutkimuslaitokselle apurahan väestökeskusten ja maaseudun asunnontarvetta koskevien laskelmien suorittamista sekä paikkakunnallisen asunnontarpeen selvityksen metodisen suunnitelman laatimista varten. Työtä on- tutkimuslaitoksessa johtanut dosentti $\mathrm{Ar}$ mas Nieminen, ja sen on varsinaisesti suorittanut valtiotieteen maisteri Aarno Strömmer.

Tehtävän ensimmäisen osan tulokset ovat valmistuneet viime vuoden jälkipuoliskolla ja kuluvan vuoden (1953) alussa; yhteenveto niistä on julkaistu Sosiaalisessa Aikakauskirjassa $3-4,1953 .{ }^{1}$ Tässä esityksessä tullaan näin ollen paneutumaan yksinomaan jälkimmäiseen osatehtävään, paikkakunnallisen asunnontarpeen selvityksen hahmotteluun.

Paikkakunnallisen asunnontarpeen selvityksen $t \mathrm{e} h \mathrm{t}$ ä vän ä on väestön todennäköisen kehityksen ja tiettyjen asuntopoliittisten normien perusteella mitoittaa lähitulevaisuuden asunnontuotannon tarve kyseisellä paikkakunnalla.. Paitsi tiettynä hetkenä vallitsevan asuntovajauksen suuruutta ja jakaantumista eri kokoisiin huoneistoihin on siis selvitettävä myös talouskuntien lisääntymisestä ja asuntokannan saneerauksesta aiheutuva lisätarve eh- 
kä lähimmän parin vuosikymmenen kuluessa sekä sen jakaantuminen eri suuruisiin asuntoihin.

Tutkijan suoritettua tehtävänsä on suunnittelijan, kunnallisen asunnontuotanto-ohjelman laatijan, ratkaistava, missä laajuudessa ja millaisin keinoin kalkyloitu tarve yritetään tyydyttää, ts. määrättävä, kuinka paljon ja minkälaisia huoneistoja suunnitelmaperiodin eri vuosina olisi rakennettava.

Asunnontarpeen selvityksen käyttö ei kuitenkaan rajoitu yksinomaan asuntopoliittisiin tarkoituksiin tämän sanan suppeassa mielessä. Tulevan rakennustoiminnan arvioiminenhan on yhdyskuntasuunnittelussa erittäin tärkeä osatehtävä, joten nyt hahmoteltavalla selvityksellä on merkitystä myös a semaka a vaa rkkitehdin työlle esim. yleiskaavaa laadittaessa. Varsin käyttökelpoiseksi viimeksi mainittuun tarkoitukseen po. selvitys muodostuu, mikäli asunnontarpeen prognoosin perustana oleva väestöennuste laaditaan niin yksityiskohtaiseksi, että myös lastentalojen, leikki- ja urheilukenttien, koulujen, vanhainkotien ym. tarpeen kalkylointi sen perusteella käy mahdolliseksi.

Esillä olevaa metodisuunnitelmaa laadittaessa on käytetty esikuvana Ruotsissa jo vuosikymmenen ajan suoritettuja vastaavanlaisia tutkimuksia. ${ }^{2}$ Kosketus selvityksen käytännölliseen, suoritukseen on saatu koottaessa Lappeenrantaa, Paraisten kauppalaa ja Haapaveden kuntaa koskevaa tilastoaineistoa ja käytäessä keskusteluja näiden paikkakuntien viranomaisten kanssa. Alkuperäisen työsuunnitelman mukaan oli näet aikomuksena suorittaa täydelliset tarvelaskelmat kyseisistä kunnista. Työn edistyessä ilmeni kuitenkin, ettei ajan ja varojen niukkuus sallinut aineiston riittävää täydentämistä erikoistiedusteluin, joten mainittuja tilastoja tullaan käyttämään vain tämän esityksen havainnollistamiseksi joissakin valituissa kohdissa.

Koska maaseutupaikkakunnan asunnontarpeen tutkimuksella on omat erikoispiirteensä, sille varataan esityksen lopussa erillinen, kysymystä tosin varsin suppeasti kosketteleva lukunsa. Siihen mennessä on tarkastelun kohteena siten lähinnä väestökeskusten - kaupunkien ja kauppalain - asunnontarve. 
Tarve-sanalla on kaksinainen merkitys, fenomenaalinen eli elämyksellinen ja funktionaalinen eli toiminnallinen. Elämyksellisenä kokemuksena asunnontarve ei luonnollisesti sovellu tilastollisen selvityksen kohteeksi. „Sen sijaan tarpeita, mm. asuntojen tarvetta, funktio na a lisessa mielessä käsitettynä voidaan ajatella tutkittavaksi myös empiirisellä pohjalla. Tutkimus on toisin sanoen kohdistettava asunnontarpeen ilmenemismuoto o n, manifestaatioon. ${ }^{3}$

Asunnontarpeen silmenemismuotonas, as unn ontarvitsi ja y k sikk ön ä, pidetään tässä esityksessä talouskuntaa. Jokaisen pysyvässä mielessä perustetun talouskunnan katsotaan siten olevan oman erillisen asunnon tarpeessa. ${ }^{4}$ Tähän asuntopolitiikan »kvantiteettinormiin» nojautuen esitetään seuraavat yhtälöt, joihin tarvelaskelmien tilastollinen suoritus - sikäli kuin on kysymys asuntojen riittävyydestä pelkkään talouskuntien lukumäärään verrattuna - tulee perustumaan:

(1) asuntojen kokonaistarve (jonakin ajankohtana) = talouskuntien lukumäärä + asuntovaranto. ${ }^{5}$

Talouskuntien lukuun on tällöin itsenäisinä yksikköinä luettava myös jo perustetut perheet, jotka vielä asuvat toisen perheen yhteydessä sen tähden, että asuntopulan vuoksi eivät ole voineet muodostaa omaa taloutta, sekä talouskunnat, joiden päämiehen työpaikka on tutkittavassa kunnassa ja jotka samasța syystä kuin edellisetkin joutuvat jatkuvasti asumaan jossakin muualla, esim. lähikunnissa.

(2) asuntovajaus (jonakin ajankohtana) = asuntojen kokonaistarve - asuntojen lukumäärä.

Asuntojen lukumäärästä on tällöin vähennettävä terveydellisistä syistä asumiseen kelpaamattomiksi tuomittavat asunnot sekä muista syistä, esim. asemakaavan toteuttảmiseksi välittömästi purettavissa rakennuksissa sijaitsevat asumnot.

(3) jonkin kauden aikana syntyvä asuntojen lisätarve = asuntojen kokonaistarve kauden lopussa - asuntojen koko- 
naistarve kauden alussa + kauden aikana »häviävien» asuntojen määrä.

Kauden aikana »häviävillä» asunnoilla tarkoitetaan yhtälössä 2 mainitun perussaneerauksen jälkeen tapahtuvaa juoksevaa »saneeraustoimintaa», jonka aiheuttavat rakennusten purkaminen ja asuntojen käyttötarkoituksen muuttaminen.

Asuntojen riittävyyden kalkyyli vertailemalla pelkästään talouskuntien ja asuntojen $1 \mathrm{uk} \mathrm{umääri} \mathrm{ä} \mathrm{ei} \mathrm{kuitenkaan} \mathrm{selvitä}$ asunnontarvetta tyhjentävästi. Asunnontarvitsijayksiköillä tulee olla kullakin oma asunto (sekä asuntovarannon suoma mahdollisuus muuttaa toiseen huoneistoon), mutta tämän tulee tyydyttää käyttäjänsä tarve myös laadullisten ominaisuuksien puolesta. Yhtälössä 2 otettiin jo huomioon huoneistojen terveydellinen asumiskelpoisuus. Sen sijaan huomiota ei ole vielä kiinnitetty muihin tyydyttävältä asunnolta vaadittaviin seikkoihin, mm. siihen, että asunnon tulee - kun kysymystä tarkastellaan yhteiskunnan onnellisen kehityksen kannalta - täyttää tietyt vaatimukset myös hu oneluvun suhteen. V́aikka asuntopolitiikan »kvantiteettinormi» olisikin toteutettu, vaikka toisin sanoen asuntovajausta ei enää olisi, tyydyttämätöntä asunnontarvetta esiintyy jatkuvasti, ellei monien yhteiskunnallisten epäkohtien yhteydessä turmiolliseksi havaittua ahtaasti asumista myös ole poistettu.

Kysymyksen havainnollistamiseksi esitetään taulukossa 1 Lappeenrannan ja Paraisten kauppalan todellisen ja toivottavan eli ns. optimiasuntokannan vertailu vuodenvaihteessa 1950/51. Esityksen yksinkertaistamiseksi oletetaan, että asuntotalous edustaa »normaalia» asunnontarvitsijayksikköä. ${ }^{6}$ Optimiasuntokanta lasketaan siten, että ahtaasti asuvat taloúdet sijoitetaan normin täyttävään minimiasuntoon. Normina taas pidetään tässä sääntöä »korkeintaan kaksi henkilöä asuinhuonetta kohden». Tällöin ei keittiötä pidetä asuinhuoneena. Se poikkeus kuitenkin tehdään, että huoneen ja keittiön asunnossa ei kolmen hengen taloutta vielä katsota ahtaasti asuvaksi.

Taulukko osoittaa selvästi, että vaikka varsinaista asuntovajausta ei enää olisikaan, esiintyy piilevää, rakenteallis t a 
Taulukko 1. Todellinen ja optimiasuntokanta Lappeenrannassa ja Paraisten kauppalassa 31. 12. 1950.

$$
\text { Lappeenranta }
$$

\begin{tabular}{|c|c|c|c|c|}
\hline Huoneita & Tod. & Opt. & Ero & Tod. \\
\hline 1 & 1337 & 897 & +440 & 417 \\
\hline $1+k$ & 2172 & 1535 & +637 & 732 \\
\hline $2+k$ & 863 & 1097 & -234 & 458 \\
\hline $3+k$ & 362 & 974 & -612 & 168 \\
\hline $4+k$ & 143 & 328 & -185 & 77 \\
\hline $5+k$ & 63 & 97 & -34 & \\
\hline $6-w+k$ & 38 & 50 & -12 & \\
\hline Yhteensä & 4978 & 4978 & \pm & \\
\hline
\end{tabular}

Parainen

Opt. Ero

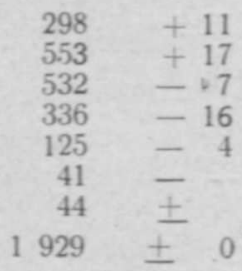

- Koska lähdetilasto ei erottele keittiö- ja keittokomeroasuntoja toisistaan, sisaltyy huoneistotyyppiin "1 h $+\mathrm{k}$ " myös "2 h + kk", vastaavasti tyyppiin "2 $\mathrm{h}+\mathrm{k}$ " myös "3 $\mathrm{h}+\mathrm{kk}$ ".

vajausta ahtaasti asumisen muodossa. Lappeenrannan kohdalla se ilmenee noin $1000: n$ ja Paraisten kohdalla 200-300 kahden huoneen ja keittiön tai sitä suuremman asunnon tarpeena.

Asunnontarvelaskelmien perustaksi on näin ollen »kvantiteettinormin» - kullekin talouskunnalle oma asunto - lisäksi otettava huonelukuun kohdistuva »kvaliteettinormi», jonka avulla voidaan osoittaa ahtaasti asumisen mittasuhteet. Siihen nojautuen ovat myös osviitat asunnontuotannon jakamiseksi eri suuruisiin huoneistoihin laadittavissa.

Ennen kuin esillä olevasta asunnontarpeen käsitteellisestä selvityksestä siirrytään varsinaiseen tarvelaskelmien hahmotteluun, on syytä lyhyesti kajota myös käsitteeseen asunnonkysyntä. On selvää, että asunnontarve ja -kysyntä ovat kaksi eri asiaa. Kysyntä ei toisin sanoen seuraa automaattisesti tarpeen ilmaantumista, vaan se riippuu lisäksi kyseisen taloussubjektin tuloista, huoneiston hankintakustannuksista, asumistottumuksista jne. Tarvitsijayksiköiden ja asunnonkysynnän kokonaismäärien kehitystä kuvaavat käyrät eivät siten ole identtiset.

Tosiasiana silti kuitenkin pysyy, että sasuntojen tarve edustaa potentia alist a kysyntää, joka pyrkii muodostumaan markkinoilla tehokkaaksi kysynnäksi, jos tietyt, lähinnä taloudellista laatua olevat tekijät sen sallivats. ${ }^{7}$ Vaikka nämä tekijät lyhyen 
ajan estäisivätkin asunnon tehokkaan kysynnän, voidaan perustellusti väittää, että »jos riittävän pitkää ajanjaksoa pidetään silmällä, asuntokannan kehityksen voidaan odottaa suurin piirtein noudattavan demografisiin tekijöihin perustuvan 'luonnollisen' asunnontarpeen kehitystä». ${ }^{8}$

\section{Asuntovajauksen arvioiminen.}

Selvityksen hahmottelu voidaan sopivasti aloittaa vallitsevasta asuntovajauksesta, joka edellä (yhtälössä 2) määriteltiin asuntojen kokonaistarpeen ja asuntojen lukumäärän erotukseksi. Määrittelyn selväpiirteisyydestä huolimatta asuntovajauksen toteaminen ei ole aivan yksinkertainen tehtävä. Näin on asian laita ennen kaikkea siksi, että käytettävissä oleva tilasto on yleensä varsin puutteellinen ja mahdollisuudet sen riittävään täydentämiseen niinikään rajoitetut. Tehtävä muodostuukin itse asiassa huolellisen a rvion laatimiseksi.

Asuntojen kokonaisvajauksen arvioiminen lienee parhaiten suoritettavissa sen eri komponenttien synteesinä. Aikaisemmin esitettyjen yhtälöiden perusteella näiden osatekijöiden luettelo on seuraava:

(a) Täysin asunnottomat (tilapäisesti esim. hotelleissa majailevat) sekä alivuokralaistaloudet. ${ }^{9}$

(b) Perheet, jotka asuntopulan pakottamina asuvat samassa taloudessa toisen, esim. omaistensa perheen kanssa.

(c) Talouskunnat, joiden päämies käy työssä selvityksen alaisella paikkakunnalla ja joiden työpaikkakunnalle muuton esteenä on siellä vallitseva asuntopula.

(d) Talouskunnat, jotka asuvat terveydellisistä syistä kelpaamattomiksi tuomittavissa asunnoissa tai rakennuksissa, jotka esim. asemakaavan toteuttamiseksi olisi välittömästi purettava.

(e) Puuttuva asuntovaranto.

Tietyt viitteet osaryhmien arvion teknillistä suoritusta silmällä pitäen lienevät paikallaan, joskin sen yksityiskohdat mm. tilastoaineiston erilaisuuksista johtuen tulevat luonnollisesti vaihtelemaan paikkakunnasta toiseen. 
Os a ry hmän (a) pätevä arvioiminen ei tuottane vaikeuksia. Väestölaskentavuosinahan sen suuruus saadaan suoraan talouskunta- ja asuntokannan inventoinnissa hankituista tilastoista, joten varsinaiseen arvioimiseen joudutaan vain välivuosina. Laskelmalle tarjoaa lähtökohdan se seikka, että asunnottomien ja alivuokralaistalouksien kokonaismäärä on sama kuin talouskuntien ja asuntojen kokonaislukujen erotus. Asuntojen määrä jonkin välivuoden, esim. vuoden 1953 päättyessä on laskettavissa rakennusviranomaisten kokoamien vuosina $1951-53$ valmistuneita ja purettuja asuntoja koskevien tietojen perusteella. ${ }^{10}$ Talouskuntien lukumäärä joudutaan arvioimaan epävarmemmalla pohjalla. Vuosittaisesta väkilukutilastosta on kuitenkin saatavissa paikkakunnan väkiluku esim. vuodenvaihteessa 1953/54. Vähentämällä siitä - esim. väestölaskennan tietojen perusteella - arvioitu laitosväestỏn määrä ja jakamalla nâin saatu yksityistalouksien väkiluku talouskuntien keskimääräistä suuruutta osoittavalla luvulla, joka sekin on arvioitavissa väestölaskennan tuloksiin nojautuen, saadaan lasketuksi talouskuntien kokonaisluku vuoden 1953 päättyessä. Kalkyloitu asunnottomien ja alivuokralaistalouksien yhteismäärä voidaan jakaa edelleen yksinäisiin henkilöihin ja eri suuruisiin perheisiin esim. väestölaskennan vastaavaa jakautumaa tai huoneenvuokralautakunnan asunnonhakijakortistoon perustuvaa tilastoa hyväksi käyttäen. Viimeksi mainitun käyttōkelpoisuutta asuntovajauslaskelmiin käsitellään vielä tuonnempana, mutta todettakoon jo tässä, että asunnottomien ja alivuokralaisperheiden määrästä se antaa yleensä luotettavan kuvan.

Asunnottomat ja alivuokralaistaloudet muodostavat eräänlaisen asuntovajauksen »keskuksen». Muut ryhmät ovat tavallaan tämän talouskuntien ja asuntojen määrien erotuksen täydennystermejä. Osaryhmät b, c ja e näet lisäävät asuntojen kokonaistarvetta, kun taas d vähentää asuntojen määrää.

O sary hm än (b) arvio on sekin suoritettavissa väestölaskennan ja huoneenvuokralautakunnan tilastojen nojalla. Edellisestä näet saadaan tiedot talouskuntien jakaantumisesta perheiden luvun mukaan. Edustavatko kaksi- tai useampiperheiset taloudet perheiden lukua vastaavaa asunnontarvetta, on kysymys, jonka ridaton ratkaisu kävisi päinsä vain itse paikalla suoritetuin tiedusteluin. Arvio voidaan kuitenkin perustellusti rakentaa silhen työhypoteesiin, että tällaisissa tapauksissa on todellinen - ja asuntovajauslaskelmassa huomioon otettava - irtautumistarve olemassa. " Kyseisen ajankohdan vastaavat tapaukset paikkakunnan asunnonhakijatilastossa on luonnollisesti syytä ottaa arvion tueksi.

Os a ry hän (c) arvioiminen muodostuu varsin pulmalliseksi, koska kysymystä valaisevaa tilastoaineistoa on olemassa erittäin niukasti. Vaikka väestökeskuksessa naapurikunnista työssä kãyvien luku tunnettaisiinkin - sehän on selvitettävissă esim. väestölaskennan aineistosta - jăă avoimeksi kysymys, missä 
määrin näiden henkilöiden asuinpaikan valinta johtuu suoranaisesti väestökeskuksessa vallitsevasta asuntopulasta. Olisi toisin sanoen selvitettävä, moniko heistä muuttaisi kyseiseen kaupunkiin tai kauppalaan, mikäli huoneiston saanti ei tuottaisi vaikeuksia. Jotain valaisua asiaan saadaan luonnollisesti asunnonhakijatilastosta, mutta jos tämän ryhmän arvio halutaan varmemmalle pohjalle, lienee ainoana mahdollisuutena tiedustelun toimeenpano paikkakunnan työnantajayrityksissä. ${ }^{12}$

Osaryhmän (d) selvittäminen on parhaiten toteutettavissa antamalla tehtävä kehnojen asuntojen osalta asunnontarkastajan ja muulta osaltaan (asemakaavalliset toimenpiteet) rakennusviranomaisten suoritettavaksi. Edellisessä tehtävässä on huomattava, että objektiivisia ohjeita sen seikan määräämiseen, milloin jokin huoneisto on katsottava asumiseen kelpaamattomaksi, on ymmärrettävästi vaikea antaa. Näin ollen arvion laatiminen jää asunnontarkastajan tosin subjektiivisen, mutta silti parasta käytettävissä olevaa asiantuntemusta edustavan näkemyksen varaan.

Esimerkkinä kehnojen asuntojen laskennasta voidaan mainita asunnontarkastajan Lappeenrannassa huhtikuussa 1953 suorittama selvitys. Sen laatijan käsityksen mukaan tällaisia asuntoja oli kaikkiaan 261 eli $5 \%$ huoneistojen koko määrästä. Yhden huoneen asuntoja oli nilistä 152, kahden huoneen 86 ja kolmen huoneen ja sitä suurempia 23. ${ }^{13}$ Pääasiallisimpana "vikana" esiintyi ylainen rappeutuneisuus ja silhen liittyvä kylmyys ja kosteus. Talouksista oli 106:ssa $1-2$ henkeä, $3-4$ hengen talouksia oli 121 ja sitä suurempia 34 .

Osaryhmän (e) eli asuntovarannon arvioiminen on puhtaasti laskennallinen toimenpide. Varannon sopivana määränä voitaneen pitää $2 \%$ :a asunnontarvitsijayksiköiden luvusta. Viímeksi mainittu taas saadaan lisäämällä talouskuntien lukumäärään ryhmät $\mathrm{b}$ ja $\mathrm{c}$.

Edellä hahmoteltujen arvioiden tultua suoritetuksi on asuntojen kokonaisvajauksen laskeminen pelkkä yhteenlaskutoimenpide. Asuntovajauksen osittelua eri suuruisiin huoneistoihin käsitellään tässä kirjoituksessa myöhemmin.

\section{Lisätarpeen arvioiminen eli asuntơprognoosii.}

Asunnontarpeen prognoosi eli lyhyesti sanoen asuntoprognoosi sisältää kaksi täysin erillistä tehtävää: talouskuntaennusteen sekä prognoosiperiodin aikana purettavien tai muuten käytöstä poistettavien asuntojen arvion. Ennen kuin ryhdytään näiden tehtävien käytännöllisen suorituksen kaavailuun, otetaan talo u skunnanmuodostus, sen tietyn vaiheen tilastollinen kuvaus 
samoin kuin sekin seikka, miten väestölliset ja muut tekijät siihen vaikuttavat, lähemmän tarkastelun alaiseksi.

Talouskunnanmuodostuksen intensiteettiä eri väestöryhmissä kuvataan ns. talouskuntafrekvensseillä, jotka ilmaisevat talouksien päämiesten suhteellisen osuuden \%:eina kyseisestä ryhmästä. Oheisessa asetelmassa esitetään kaikkien väestökeskusten sekä erikseen Lappeenrannan ja Paraisten 20 vuotta täyttäneen väestön talouskuntafrekvenssit eri siviilisäätyrymissä vuodenvaihteessa $1950 / 51:{ }^{14}$

Miehet

- naimattomat

- naimisissa olevat

- naimisissa olleet

Väestökes- Lappeenranta kukset

Parainen

31.0

86.7

65.8

48.3

11.6

720
25.9

75.5

57.4

46.5

23.8

72.7
15.5

79.4

69.1

46.9

19.1

76.5

Koska väestölaskennassa jätettiin tiedustelulomakkeen täyttäjän itsensä päätettäväksi, kumpi aviopuolisoista oli merkittävä talouskunnan päämieheksi, tilastossa esiintyy sellaisina myös koko joukko aviovaimoja. Laskemalla naimisissa olevien miesten ja naisten frekvenssit yhteen voidaan todeta, että lähes kaikki avioparit, 98-99 \%, ovat muodostaneet oman talouskunnan. Leskien ja eronneiden luvut ovat huomattavasti pienemmät. Puolison kuolema tai avioèro aiheuttavat toisin sanoen sen, että noin kolmannes näistä henkilöistä - miehistä jonkin verran enemmän kuin naisista - sulautuu toiseen talouskuntaan. Naimattomien henkilöiden frekvenssit ovat säännöllisesti vieläkin pienemmät, miehillä $20-30$ $\%$ ja naisilla $40-50 \%$.

Edelleen on osoitettavissa, että talouskuntien päämiesten suhteellinen osuus vaihtelee eri ikäluokissa. Tämä seikka selviää taulukosta 2, jossa väestökeskusten ikäluokittain eritellyt frekvenssit esitetään. 
Taulukko 2. Talouskunnan pä̈miehet sadasta vastaavassa ryhmässä olevasta henkilöstä väestökeskuksissa 31, 12. 1950.

$\begin{array}{cllllll}\text { Ikä, v. } & \begin{array}{l}\text { Nai } \\ \text { mat- } \\ \text { tomat }\end{array} & \begin{array}{c}\text { Miehet } \\ \text { Naimi- } \\ \text { sissa } \\ \text { olevat }\end{array} & \begin{array}{c}\text { Naimi- } \\ \text { sissa } \\ \text { olleet }\end{array} & \begin{array}{c}\text { Nai- } \\ \text { mat- } \\ \text { tomat }\end{array} & \begin{array}{c}\text { Naiset } \\ \text { Naimi- } \\ \text { sissa } \\ \text { olevat }\end{array} & \begin{array}{c}\text { Naimi- } \\ \text { sissa } \\ \text { olleet }\end{array} \\ 20-29 & 19.1 & 82.9 & 43 \cdot 2 & 27.2 & 5.0 & 520 \\ 30-39 & 44.4 & 87.5 & 56.9 & 53.6 & 10.5 & 82.3 \\ 40-49 & 55.6 & 86.7 & 67.7 & 64.1 & 15.2 & 89.6 \\ 50-59 & 641 & 87.3 & 75.5 & 69.5 & 17.2 & 81.8 \\ 60-69 & 70.7 & 89.0 & 75.5 & 67.1 & 14.4 & 656 \\ 70-\text { w } & 71.3 & 91.8 & 59.3 & 65.8 & 8.8 & 52.0 \\ 20-\text { w } & 31.0 & 86.7 & 65.8 & 483 & 11.6 & 72.0\end{array}$

Ikäluokassa $20-29 \mathrm{v}$. on esim. naimattomista miehistä talouksien päämiehiä $19.1 \%$ ja naimattomista naisista $27.2 \%$. Iän mukana luvut kohoavat, niin että ne eläkeikään ehdittäessä ovat jo $70 \%$ :n paikkeilla. Leskien ja eronneiden frekvenssit nousevat niinikään iän mukana, joskin ne vanhemmissa luokissa jo hiukan laskevat. Naimisissa olevien ikäluokkavertailu ei myöskään jää vaille erikoispiirteitään. Yleensä avioparit kutakuinkin 100-prosenttisesti muodostavat oman talouskuntansa. Nuorimman ikäluokan yhteenlaskettu frekvenssi, joka jää tuntuvasti alle $90 \%$, osoittaa kuitenkin, että varsin monissa vastasolmituissa avioliitoissa oman talouden perustaminen on saanut jäädä odottamaan otollisempaa ajankohtaa. Tähän seikkaan kiinnitettiin huomiota jo edellä asuntovajauksen eri komponentteja käsiteltäessä.

Koska talouskuntien kokonaisluku jonakin ajankohtana on sama kuin niiden tulojen summa, jotka saadaan kertomalla eri väestöryhmissä olevien henkilöiden määrä vastaavilla frekvensseillä, voidaan talouskunnanmuodostukseen vaikuttavat tekijät jakaa kahteen ryhmään: niihin, jotka aiheuttavat muutoksia kyseisten väestöryhmien paljouksissa, sekä niihin, jotka aiheuttavat muutoksia näiden ryhmien talouskunnanmuodostuksen intensiteetissä. ${ }^{15}$

Mitä ensinnäkin väestöllisiin tekijöihin: tulee, on syytä tähdentää sitä, että kysymyksessä ovat talouskuntia muodostavat ikäluokat. Paikkakunnan väkiluvun kasvun ei näin ollen 
ilman muuta tarvitse aiheuttaa talouskuntien luvun ja samalla asunnontarpeen nousua. Vasta kun lisäys tulee ikäluokkien 20-w osalle, on lukumääräisen asunnontarpeen kasvu seurauksena. Se saattaa olla seurauksena siinäkin tapauksessa, että tämän väestönosan kokonaismäärä pysyisi ennallaan, mutta tapahtuisi siirtoa alempien talouskuntafrekvenssien ryhmistä korkeampien frekvenssien ryhmiin. Näin on asianlaita väestön »vanhetessa» tai silloin, kun naimisissa olevien osuus vilkkaan avioitumisen johdosta kasvaa naimattomien suhdeluvun kustannuksella. Tekijät, jotka väestön paljouteen ja sisäiseen rakenteeseen vaikuttavina on prognoosissa otettava huomioon, ovat väestön ikärakenteen muuttuminen, syntyvyys, kuolevuus, muuttoliike, avioituminen ja avioerot.

Talouskuntafrekvensseihin vaikuttavat ennen kaikkea taloudelliset seikat, mutta myös nykyajalle ominainen perhesiteiden höltyminen on varteenotettava tekijä. Lähtökohtana tulevaisuutta koskeville otaksumille voitaneen pitää avioparien lähes täydellistä irtautumista itsenäisiksi talouskunniksi samoin kuin naimattomien henkilöiden talouskuntafrekvenssien jatkuvaa kasvamista.

Asuntoprognoosin käytännöllisen suorituksen hahmottelu jaetaan seuraavassa kolmeen osaan: väestöprognoosiin, varsinaiseen talouskuntaprognoosiin sekä laskelmakaudella »häviävien» asuntojen arvioon.

\section{Väestöprognoosi.}

Väestöprognoosin ja siihen perustuvien muiden, mm. asunnontarpeen, laskelmien yleisen luonteen ymmärtämiseksi on aluksi tähdennettävä sitä, että itse prognoosi on lukuisten tulevaa kehitystä koskevien ot a ksumien laskennallinen lopputulos. Selvää on, että sen paikkansapitävyys riippuu suuresti siitä, kuinka todenmukaiseen käsitykseen tähänastisesta kehityksestä, nykyisestä tilanteesta ja tulevaisuuden mahdollisuuksista nämä työhypoteesit perustuvat. Yhtä selvää kuitenkin on, että prognoosi ei 
sellaisenaan koskaan toteudu, olkootpa otaksumat kuinka tunnontarkasti laadittuja tahansa. Tämä ei suinkaan merkitse sitä, että laskelman suoritus olisi täysin tarkoituksetonta. Todennäköisen kehityksen arvio on välttämätön kaikelle suunnittelulle. Tulevaisuutta ei voida tuntea, mutta väestöprognoosin arvo onkin siinä, että se »projisioi» tulevaisuuteen sen, mikä tällä hetkellä on tunnettua. Erilaisten epävarmuusmomenttien huomioon ottamiseksi on todennäköisen ennusteen lisäksi syytä laatia marginaaliarviot, jotka ilmaisevat prognoosintekijän käsityksen siitä, kuinka kauas todennäköisestä arviosta kehityksen voidaan enintään odottaa poikkeavan.

Väestöennusteen tehtävänä on arvioida väestön lukumäärä eri sukupuoli-, siviilisääty- ja ikäryhmissä prognoosiperiodin tiettyinä ajankohtina.

Mitä ensinnäkin prognoosiperiodin pituuteen tulee, on muistettava, että mitä pitemmälle tulevaisuuteen laskelma ulotetaan, sitä suuremmaksi kasvaa myös epävarmuusmarginaali. Koska kahden lähimmän vuosikymmenen aikana talouskuntia muodostavaan ikään tulevat henkilöt ovat jo olemassa ennusteen lähtöajankohtana, on perusteltua valita periodiksi 20 vuotta. Näin menetellenhän kauden aikana syntyviksi otaksutut ikäluokat eivät ehdi heikentää itse talouskuntalaskelman luotettavuutta. Jos kysymyksessä olisi yksinomaan asunnontarpeen ennuste, voitaisiin siten jättää syntyvyys kokonaan huomiotta. Koska nuorten ikäluokkien ottaminen mukaan kuitenkin lisää tutkimuksen käyttökelpoisuutta muussa yhdyskuntasuunnittelussa aivan oleellisesti, ei tällaiseen rajoitukseen ole aihetta.

Laskentatyön vähentämiseksi prognoosi suoritetaan viisivuotisjaksoin. Mikäli kysymyksessä on väestöennuste esim. vuoteen 1970 saakka, on siis vuoden 1950 väestötaulu lähtökohtana - väestö iän (viisivuotisryhmin), sukupuolen ja siviilisäädyn (naimattomat, naimisissa olevat sekä lesket ja eronneet) mukaan - arvioitava väestön rakenne vuosina 1955, 1960, 1965 ja 1970.

Teknillisenä suorituksena laskelman kulku on seuraava: Ku- 
kin vuoden 1950 viisivuotisikäryhmä siirretään luokkaa ylemmäksi vuonna 1955. Sitä ennen siitä kuitenkin vähennetään ikäryhmän otaksuttu kuolleiden määrä ja lisätään (vähennetään) sen muuttovoitto (-tappio). Kauden aikana otaksuttu syntyneiden kokonaisluku korjataan ikäluokan 0-4 v. kuolevuus- ja muuttoliikeotaksumien mukaisesti, jolloin saadaan 0-4-vuotiaiden määrä 1955. Kunkin ikäluokan jakaantuminen eri siviilisäätyryhmien osalle lasketaan sen jälkeen kyseisestä jakaantumasta laaditun otaksuman mukaisesti. Näin saatu vuoden 1955 väestötaulu »siirretään s sen jälkeen edelleen samalla tavalla seuraaviin prognoosiajankohtiin.

Ennusteen perustana oleviin ot a ks u mi in on luonnollisesti kiinnitettävä suurta huomiota. Eräät yleiset ohjeet niiden laatimiseksi lienevät paikallaan.

$\mathrm{K}$ u o lem a nva a a eri ikäluokissa on väestökeskuksissa yleensä hiukan alhaisempi kuin maaseudulla. Tämä eroavuus eri paikkakuntien kesken on kuitenkin niin merkityksetön (ja se on jatkuvasti pienenemään päin), että varsin hyvin voidaan käyttää koko maan kuolleisuustauluja paikkakunnallisissakin prognooseissa. Laskelmassa tarvittavien lukujen on ilmaistava, moniko kuhunkin miesten ja naisten viisivuotisikäryhmään kuuluva henkilö tulee todennäkőisesti olemaan elossa viiden vuoden kuluttua. Tällaiset eloonjäämistodennäköisyysluvut on osaksi Suomessa todettuun kehitykseen, osaksi Ruotsin lukuihin perustuen laskettu viisivuotiskausille $1951-55 \ldots 1996-2000$ tilastollisen päätoimiston vuonna 1949 julkaisemissa Suomen tulevaa väestônkehitystă koskevissa laskelmissa. Koska eloonjäämistodennäköisyyden nouseva suunta on näin tullut pätevästi arvioiduksi, on tämän työn tuloksia syytä käyıtãä hyväksi myōs hahmottelun alaisissa paikallistutkimuksissa. Liftteessä 1 esitetään kyseisen eloonjäämistodennäköisyysprognoosin otaksuman 3 luvut vilisivuotiskausina 1951 -55 ... 1966 -70. Vaihtoehtoisten kuolevuusotaksumien käyttăminen ei ole tarpeen.

M u uttoliikettä koskevissa otaksumissa on arvioitava, kuinka monta eri ikäistä miestä ja naista on paikkakunnan muuttovoitto tai -tappio prognoosijakson viisivuotiskausina. Selvää on, että otaksumien perustaksi olisi tāhänastisen kehityksen lisäksi tutkittava myös paikkakunnan elinkeinoelämān kehitysmahdollisuudet ja niiden mukainen työvoiman tarve tulevaisuudessa. " Käytännössä elinkeinoelämän "absorbointikyvyn" tutkimus tarkkoine eri toimialojen analyyseineen, niiden markkinoiden kehitysmahdollisuuksien selvittelyineen ja yritysten omien suunnitelmien varteenottamisineen kohtaa kuitenkin vaikeuksia tehtävän edellyttämän primäărlaineiston kokoamiseen käytettävissä olevan ajan ja varojen niukkuuden vuoksi. Näin ollen jouduttaneen otaksumat perus- 
tamaan kutakuinkin yksinomaan tähänastisen muuttoliiketilaston tarkasteluun. Riittävän taustan otaksumille tarjonnee kahden kolmen viime vuosikymmenen kehitys, jossa taloudellisten tekijöiden, suhdanteiden, vaikutusta voidaan havainnoida jo varsin monipuolisesti. Kuten jo aikaisemmin viitatiin, on todennäköisen kehityslinjan lisäksi syytä ottaa huomioon "odottamattoman suuren" ja "odottamattoman pienen" muuttovoiton (tai -tappion) mahdollisuudet. Kuriositeetin vuoksi voidaan ennuste laskea myös otaksuen, ettei muuttoliikettä ole laisinkaan. Tämä vaihtoehto on luonnollisesti puhtaasti teoreettinen, mutta sikäli mielenkiintoinen, että se tekee mahdolliseksi mitata muissa vaihtoehdoissa otaksutun muuttoliikkeen vaikutuksen asunnontarpeeseen. Muuttovoiton (tai -tappion) sukupuoli- ja ikäjakautuma on konstruoitavissa paikkakunnan aikaisemman muuttoliiketilaston perusteella. Ikäluokan muuttovoitosta (-tappiosta) tietyn viísivuotiskauden aikana lisätään (vähennetään) puolet kyseiseen ja puolet seuraavaan koko väestön ikäluokkaan kauden lopussa. Näin on meneteltävä, koska muuttaneista keskimäärin puolet siirtyy ennen kauden päättymistä seuraavaan ikäluokkaan.

Sivili isä ty jaka u tuma miesten ja naisten eri ikäluokissa on Ruotsin tutkimuksissa yleensä laskettu käyttämällä basisvuoden todettua suhteellista jakautumaa. Nilssä ei toisin sanoen ole katsottu mahdolliseksi tai tarpeelliseksi tehdä erillisiä olettamuksia jokaisesta siviilisäätyryhmitykseen vaikuttavasta tekijästä (eri ikäluokkien avioitumisesta ja avioeroista sekä kuolleisuudesta ja muuttoliikkeestä si 7ililisäädyn mukaan), vaan on tyydytty työhypoteesiin ryhmien suuruussuhteiden muuttumattomuudesta. ${ }^{17}$ Onkin todettava, että eri ikäluokkien sivililisäätyjakautumien ennakoiminen on silhen vaikuttavien lukuisten tekijöiden vuoksi erittäin vaikea probleema. Mikäli tähänastisen kehityksen tarkastelu ei tunnu antavan aihetta muuhun menettelyyn, onkin jo työnsäästön kannalta paikallaan lähteä otaksumasta, että eri ikäryhmien siviilisäätyjakautumat pysyvät prognoosijakson aikana samana kuin lähtöajankohtana. Naimisissa olevien naisten lukumäärä on kuitenkin tarkistettava miesten vastaavan luvun mukaiseksi.

Vaikka syntyvy sotaksuma ei itse asuntoprognoosin kannalta olekaan välttämätön, se on kuitenkin syytä ottaa mukaan. Otaksuma voidaan perustaa esim. yleisen hedelmällisyysluvun - syntyneiden lukumäärä suhteessa 1000 :een $20-45$ vuoden iässä olevaan naiseen - tähänastiseen kehitykseen. Esimerkkinä mainittakoon Eskilstunan tutkimus (ks. lähđeviitettä 2), jossa tehdään kaksi otaksumaa. Maksimivaihtoehdossa kyseinen luku on sama kuin vuonna 1945 , toisen vaihtoehdon mukaan alempi vastaten vuoden 1943 tasoa. Syntyneiden sukupuolijakautumasta on myös tehtävä otaksuma. ${ }^{12}$

\section{Talouskuntaprognoosi.}

Talouskuntaennusteen laskennallinen suoritus on varsin yksinkertainen. Kunkin prognoosiajankohdan väestötaulun tultua las- 
ketuksi sen eri ryhmät kerrotaan vastaavilla talouskuntafrekvensseillä. Tulot lasketaan yhteen, jolloin summa osoittaa talouskuntien eli asunnontarvitsijayksiköiden luvun. Asuntojen kokonaistarpeen saamiseksi lisätään lukuun vielä $2 \%: n$ asuntovaranto. Mikäli talouskuntafrekvenssien kehityksestä laaditaan vain yksi otaksuma, tulee vaihtoehtoja näin ollen yhtä monta kuin väestöennusteita.

Vaikka itse tehtävän teknillinen suoritus onkin mutkaton, aiheuttaa frekvenssien kehitystä koskevan otaksuman laatiminen varmasti vaikeuksia. Kysymyksen valaisemiseksi esitetään seuraavassa, miten kyseinen ongelma on ratkaistu.Sandvikenin, Skövden ja Malmön paikallistutkimuksissa (ks. lähdeviitteitä 2 ja 17).

Sandvikenin vuosille 1940-1955 lasketussa asuntoprognoosissa ovat perustana asuntotalousfrekvenssit ${ }^{10}$ vuodelta 1939. Otaksuma nilden kehityksestä on perusteluineen seuraava: Frekvenssit vaihtelevat luonnollisesti taloudellisten suhdanteiden mukana, mutta pitkällä tähtäimellä on luultavaa, että tulotason paraneminen ja korkeampi asumistaso aiheuttavat niliden kohoamisen, etenkin naimattomien miesten ja naisten ryhmissä. Tämä voi tuskin kuitenkaan tapahtua ennen kuin muutamien vuosien kuluttua asuntopulan helpottuessa, minkä vuoksi frekvenssit edellytetään muuttumattomiksi vuoteen 1946 saakka. Kaudella 1946-50 oletetaan naimattomien frekvenssien kuitenkin lisääntyvän $10 \%$, samoin kaudella 1950-55.

Skövden asuntoprognoosi vuosille $1945-65$ on laskettu lähtōvuoden frekvenssein. Talouskuntien jatkuva pirstoutuminen ("hushallssprängningen") ell vanhempiensa luona tai muissa talouksissa asuvien naimattomien henkilöiden irtautuminen itsenäisiksi asunnontarvitsijoiksi on kuitenkin otettu huomioon lisäämällä naimattomien frekvenssejä vuonna 1950 ikäluokissa $20-40$ v. $5 \%$ :lla. Sama korotus on suoritettu myös 1955. Todennäköisessã ennusteessa ei vuosien 1960 ja 1965 lukuja ole enää nostettu, koska yleisen asumistason paranemisen on oletettu aiheuttavan pysähtymisen talouksien pirstoutumisessa. Maksimiprognoosissa sen sijaan on edellytetty naimattomien frekvenssien $5 \%: n$ kasvu vielä $1955-60$.

M a $1 \mathrm{~m}$ ö n asuntoprognoosi perustuu vuoden 1950 frekvensseihin. Naimisissa olevien luvut on oletettu konstanteiksi koko periodin - 1950-1970 - aikana. Sen sijaan leskien ja eronneiden frekvenssien on otaksuttu kohoavan jonkin verran. Sama koskee myös naimattomien lukuja. Erikoista on kuitenkin se, että niissä on tehty jo lähtövuonna korjaus korottamalla frekvenssejä asunnonvälitykseen ilmoittautuneiden naímattomien asunnonhakijoiden määrällă.

Suomen paikkakunnallisissa asúnnontarpeen selvityksissä voi- 
taneen suositella vastaavanlaisia ratkaisuja. Naimisissa olevien frekvenssejä konstruoitaessa on kuitenkin lähtöajankohdan (1950) lukuja korotettava asuntovajauksen termiä (b) - irtautumistarvetta edustavien perheiden määrää - vastaavasti.

Kun talouskuntien lukumäärä ja sitten asuntojen kokonaistarve - asuntovaranto mukaanluettuna - kunkin viisivuotiskauden päättyessä on tullut arvioiduksi, onkin kauden nettomääräisen lisätarpeen laskeminen pelkkä vähennystehtävä. Lisätarpeen koko määrän saamiseksi on kuitenkin vielä suoritettava kauden aikana »häviävien» asuntojen arvio.

Prognoosikaudella »häviävien» asuntojen lukumäärän arvioiminen.

Tiedot tähänastisesta purkamalla tai käyttötarkoitusta muuttamalla tapahtuneesta asuntojen poistamisesta, »häviämisestä», ovat sangen vähäiset. ${ }^{20} \mathrm{Kun}$ lisäksi otetaan huomioon se seikka, että huoneenvuokralautakunnan luvatta rakennusta, jossa on yksikään asunto, ei saa purkaa eikä asuinhuoneistoa muuttaa toiseen käyttöön tai yhdistää muihin huoneistoihin, ymmärretään otsikon ilmaiseman tehtävän komplisoitu luonne.

Tätä nykyä huoneistojen poistaminen asumiskäytöstä on miltei olematonta. Varsinaisen purkamistoiminnan osalta se on todettavissa $\mathrm{mm}$. virallisesta asunnontuotantotilastosta, jonka mukaan väestökeskuksissamme purettiin vuosina 1948-52 keskimäärin 290 huonetta eli noin 150 huoneistoa vuodessa; tarkkaa lukua viimeksi mainituista ei ole saatavissa. Mikäli asuntopula ja huoneenvuokrasäännöstely nykyisessä laajuudessaan tulevat edelleenkin jatkumaan, on näin ollen selvää, ettei asuinhuoneistojen käytöstä poistaminen tule meillä olemaan lisätarpeeseen sanottavastikaan vaikuttava tekijä.

Mitä varsinaiseen purkamistoimintaan tulee, on toisaalta kuitenkin ilmeistä, ettei asuntojen tarpeen tutkimuksessa ole syytä pitää perustana tätä asuntososiaaliselta kannalta täysin riittämätöntä saneerausta, vaan on lähdettävä sen toi vottavast a suuruudesta. 
Tällöin tulee tietysti ratkaistavaksi kysymys, mikä otetaan purkamisen tavoitteeksi. Sellaisena voidaan ensinnäkin pitää sitä, että saneerauksen tulee olla riittävä slummiutumisen - asuntokannan »yli-ikäistymisen» ja yleisen rappeutumisen - ehkäisemiseksi. Tässä viitattakoon siihen, että lähtöajankohdan saneeraustarve, terveydellisistä syistä kelpaamattomiksi tuomittavat asunnot, otettiin huomioon jo edellä asuntovajauksen arviota kaavailtaessa. Prognoosijakson kuluessa purkamiskypsiksi ehtivien asuntojen määrä riippuu luonnollisesti ratkaisevasti kunkin paikkakunnan asuntokannan laadusta, lähinnä sen iästä. Tähän seikkaan on arviota laadittaessa näin ollen syytä kiinnittää huomiota.

Eräinä viitteinä tehtävää silmällä pitäen voidaan esittää, että Ruotsin väestökeskuksissa »normaalin» saneerauksen vuosittainen määrä arvioidaan noin $3 \%$ : ksi asuntokannasta. ${ }^{21}$ Malmön jo aikaisemmin mainitussa asuntoprognoosissa sasuntojen poisto muihin tarkoituksiin» - puirkamisen sekä yhdistämisen ja toiseen käyttöön siirtämisen johdosta - arvioidaan kuitenkin vain noin $2 \%$ : ksi eli 600 huoneistoksi jokaisen viisivuotiskauden $1951-55$ ... 1966-70 aikana. ${ }^{22}$

Yleensä Ruotsin asunnontarpeen selvityksissä suoritetaan tarvittavan saneeraustoiminnan arvio kuitenkin toisella pohjalla. Siihen kytketään näet tavallisesti a h t a a st i a s u mise n poistamisen - asumistason yleisen kohottamisen - tavoite. Lähtökohtana pidetään ss. 99-100 esitettyyn tapaan laskettua todellisen ja optimiasuntokannan välistä eroa, joka säännönmukaisesti osoittaa perheasuntojen vajausta ja enintään 1 huoneen ja keittiön asuntojen tuntuvaa ylijäämää. Saneeraustarpeen suuruutta arvioitaessa onkin tavoitteena juuri tämän »ylijäämävaraston» hävittäminen. Niinpä esim. Sandvikenin asuntohuoltosuunnitelmassa otetaan 340 ala-arvoisen asunnon lisäksi purettavina huomioon myös 540 pienasuntoa, jotka käyvät tarpeettomiksi, mikäli asumisväljyyteen kohdistuva tavoite toteutetaan. ${ }^{23}$

Perustelemattakin on selvää, että meidän oloissamme asuntojen lisätarpeen arvion paisuttaminen edellä kuvatulla tavalla on toistaiseksi vailla todellisuuspohjaa. Sen sijaan Malmön tutkimuk- 
sen mukainen menettely saneeraustarpeen laskemiseksi tuntuu sopivalta. Tämä ei kuitenkaan tarkoita sitä, että ahtaasti asumisen mukaan vetäminen laskelmiin - todellisen ja optimiasuntokannan vertailu - olisi täysin merkityksetöntä. Asuntovajauksen ja lisätarpeen tultua arvioiduksi on nimittäin tehtävänä osviittojen löytäminen arvion nojalla suunniteltavan asunnontuotannon jakamiselle eri suuruisiin huoneistoihin. Tässä tehtävässä, johon seuraavassa siirrytään, tiedot ahtaasti asumisesta ovat kyllä tarpeen.

\section{Eri suruisten asuntojen tarve.}

Huoneluvultaan eri suuruisten asuntojen tarve riippuu luonnollisesti siitä, millainen on asunnontarvitsijayksikköjen suuruusjakautuma ja millainen asunto kunkin kokoiselle tarvitsijayksikölle »varataan».

Kysymyksen havainnollistamiseksi esitetään taulukossa 3 eri kokoisten tarvitsijaryhmien (asuntotalouksien, ks. viitettä 6) prosentuaalinen jakaantuminen niiden käytässä olevien asuntojen huoneluvun mukaan Lappeenrannassa vuoden 1950 päättyessä. Huomataan, että enin osa 1 hengen talouksista asuu hellahuoneissa (yksiöissä), 2-6 hengen talouksista huoneen ja keittiön asunnoissa ja sitä suuremmista talouksista 2 huoneen ja keittiön huoneistoissa. Silti ovat muunkin kokoiset asunnot edustettuina, vieläpä säännönmukaisesti niin, että mitä suuremmasta taloudesta on kysymys, sen suuremmaksi kasvaa monihuoneisten asuntojen osuus pienasuntojen kustannuksella. Asunnontarpeen rakenteellista muodastusta ajatellen on näin ollen selvää, että siihen vaikuttavat sekä talouskuntajakautuman että asumistason muutokset: pienten talouksien suhteellinen kasvu lisää vastaavasti pienasuntojen tarvetta, kun taas pyrkimyksillä väljempään asumiseen on päinvastainen vaikutus.

Asuntovajauksen ja lisätarpeen eri suuruisiin huoneistoihin jakamista varten on ensinnäkin määrättävä a s u m i s t a s o, m ih in suunnittelun alaisella asunnontuotannolla py ritään. Kysymyksen ratkaiseminen ei luonnollisesti kuulu tutkimuksen laa- 
Taulukko 3. Asuntotalouksien prosentuaalinen jakaantuminen asunnon huoneluvun mukaan Lappeenrannassa 31. 12. 1950.

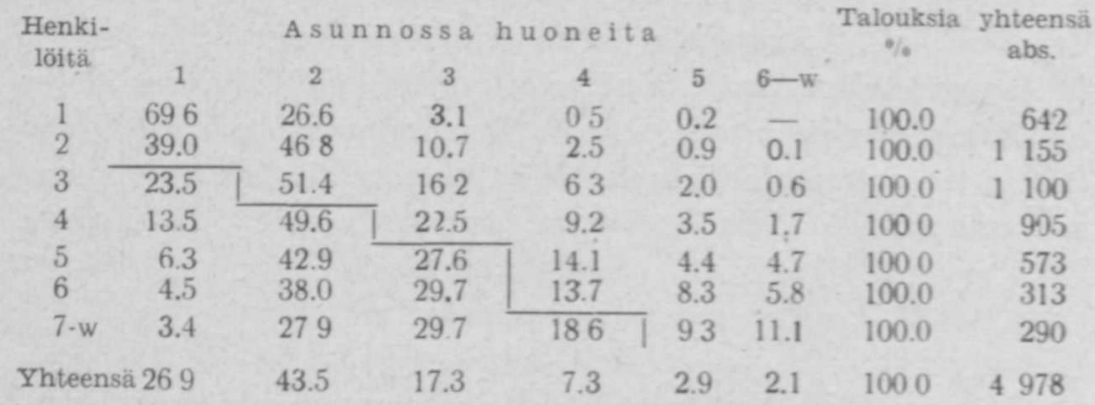

tijalle, vaan tuotannon suunnittelijalle. Varsin hyvin käynee kuitenkin päinsä, että tutkija suorittaa laskelmat vaihtoehdoin esim. seuraavasti: Miten tuotannon tulisi jakaantua, jotta

- nykyinen asumistaso säilyisi,

- hiljalleen tapahtuva »spontaaninen» asumistason kohoaminen kävisi mahdolliseksi,

- ahtaasti asuminen saataisiin suunnitelmaperiodin aikana poistetuksi joko kokonaan tai johonkin rajaan saakka.

Laskelmat voidaan ehkä parhaiten suorittaa kertomalla taulukon 3 tapaan konstruoiduilla sumistasosarjoilla» vastaavan suuruisten talouskuntien lukumäärä - asunnontarvitsijayksikköjen suuruusjakautuman arviointiin siirrytään tuonnempana - kyseisenä prognoosiajankohtana. Ensimmäisessä vaihtoehdossa käytetään lähtökohdan lukuja sellaisinaan. Asumistason »spontaanisen» kohoamisen huomioon ottamiseksi keskimmäisessä vaihtoehdossa on luonnollisesti tutkittava lukujen tähänastinen kehitys. Tähän tarkasteluun enempää kuin sen nojalla laadittavien otaksumien hahmotteluun lukusarjojen vastaisesta muuttumisesta ei tässä yhteydessä kuitenkaan ryhdytä.

Paikkakunnallisissa asunnontarpeen selvityksissä Ruotsissa on tarpeen jakaantuminen eri kokoisiin huoneistoihin melkein poikkeuksetta laskettu kolmannessa vaihtoehdossa esitetyllä tavalla. Esimerkkinä mainittakoon Eskilstunan tutkimus, jossa on lähtö- 
kohdaksi otettu vuonna 1945 normin »korkeintaan kaksi henkilöä asuinhuonetta-kohden» mukaan vallinnut ahtaasti asuminen ja otaksuttu sen tasaista tahtia - $25 \%$ kunkin viisivuotiskauden aikana - tulevan poistetuksi vuoteen 1965 mennessä. ${ }^{24}$ Vastaavanlainen menettely sovellettuna Lappeenrannan lukuihin taulukossa 3, jossa »normiviiva» on vedetty sivulla 99 esitetyn tavoitteen mukaan, tietäisi sitä, että viivan alapuolella olevia lukuja vähennettäisiin kunakin prognoosiajankohtana neljänneksellä alkuperäisestä määrästä, kun taas normin täyttävän minimiasunnon kohdalla olevaa lukua lisättäisiin vastaavasti.

Mitä talouskuntien suuruusjakautuman kehityksestä tehtävään otaksumaan tulee, voitaneen sen yleiseksi taustaksi todeta, että viime vuosikymmenien aikana talouskuntien keskimääräinen koko on jatkuvasti pienentynyt. Lähinnä tämä ilmiö johtuu perheiden lapsiluvun pienenemisestä, mutta myös talouksien pirstoutumisesta, täysi-ikäisten naimattomien henkilöiden kasvavasta halusta elää itsenäisesti omana talouskuntana.

Esimerkkinä ja ohjeeksi Suomen paikkakunnallisia asunnontarpeen selvityksiä silmällä pitäen esitettäköön talouskuntien prosentuaalisen jakautuman kehityksestä Eskilstunan tutkimuksessa laadittu otaksuma ${ }^{25}$ :

$\begin{array}{crrrrr}\begin{array}{c}\text { Taloudessa } \\ \text { henkilöitä }\end{array} & 1950 & \text { r955 } & 1960 & 1965 & 1970 \\ 1 & 14.2 & 14.9 & 158 & 166 & 17.0 \\ 2 & 300 & 29.0 & 286 & 28.1 & 27.6 \\ 3 & 28.4 & 27.7 & 267 & 26.6 & 26.5 \\ 4 & 15.5 & 15.9 & 162 & 16.6 & 16.8 \\ 5.6 & 98 & 10.1 & 1.2 & 9.8 & 10.0 \\ 7 \text { w } & 2.2 & 2.4 & 2.5 & 2.3 & 2.2 \\ \text { Yhteensä } & 1000 & 1000 & 100.0 & 1000 & 1000\end{array}$

Tämän otaksuman perustana on käsitys, että Eskilstunan jakautuma lähenee yhä enemmän kaikkien väestökeskusten vastaavaa sarjaa. Yhtymisen on oletettu tapahtuvan vuonna 1960 . Väestökeskusten kyseinen lukusarja taas on saatu Bostadssociala utredningen'in laatimasta ennusteesta, joka perustuu talouskuntajakautuman todettuun kehitykseen vuosina 1920-1939. ${ }^{26}$ Kuten 
nähdään, otaksuma edellyttää pienperheiden $-2-3$ hengen talouksien - osuuden vähenemistä, kun taas yksinäisten henkilöiden samoin kuin 4 hengen talouksien osuus kasvaa. Sitä suurempien talouksien suhdeluku on oletettu kutakuinkin muuttumattomaksi.

Asuntovaja uksen jakamisessa eri kokoisiin huoneistoihin voidaan menetellä esim. seuraavasti: Asuntotalouksien jakautuma henkiloluvun mukaan korjataan asuntovajauksen termien $(\mathrm{a}-\mathrm{c})-$ ks. s. 101 mukaisesti sekä lisäämällä kuhunkin ryhmään vielä asuntovarantoa vastaava määrä $(2 \%)$. Korjatut talouksien määrät kussakin suuruusryhmässä jaetaan sen jälkeen eri kokoisten asuntojen osalle taulukon 3 osoittamaan tapaan todettuja suhdelukusarjoja käyttäen. Näin kalkyloidun asuntojen kokonaistarpeen jakaantumisen eri suuruisiin asuntoihin ja todellisen asuntokannan vertailu osoittaa kunkin asuntotyypin vajauksen nettomääräisenä. Kokonaislukujen saamiseksi on nettolukuihin lisättävä vielä saneerattavien huoneistojen määrä kyseisessã ryhmässä.

Lis ätarpeen osittamiseksi eri suuruisiin asuntoihin lasketaan ensin kokonaistarpeen jakaantuminen eri huoneistotyyppeihin kunakin prognoosiajankohtana. Tehtävä suoritetaan tarvitsijayksiköiden henkilöluvusta ja asumistasosta edellä kaavailtuun tapaan laadittujen otaksumien perusteella. Kauden aikana syntyvän lisätarpeen jakaminen erilaisiin huoneistoihin on sen jallkeen pelkkä vähennystehtävä. Jälleen on muistettaya, ettă näin laskettuun nettomääräiseen lisätarpeeseen on vielä lisăttävã aikaisemmin mainittu kauden kuluessa "häviävien" asuntojen luku.

\section{Selvityksen tilastoaineisto.}

Edellä on hahmoteltu paikkakunnallisen asunnontarpeen selvityksen periaatteet ja teknillinen suoritus. Sen sijaan ei ole vielä kiinnitetty huomiota sellaiseen seikkaan kuin tilastoaineiston hankkimiseen. Tämä tehtävä aiheuttanee selvityksen laatijalle kuitenkin sitä suuruusluokkaa olevan ongelman, että on perusteltua paneutua siihen hiukan syvemmälti, kuin mitä edellä esityksen eri vaiheissa on tapahtunut.

Tarkastelu kohdistetaan ensin väestöennusteessa tarvittavan tilaston lähteisiin. Sen jälkeen käsitellään varsinaisten tarvelaskelmien aineistoa, toisin sanoen talouskunta- ja asuntotilastoa. On huomattava, että selonteko koskee ensi sijassa virallista, valtion viranomaisten kokoamaa materiaalia. Sen ohella selvityksen laa- 
tijan on aiheellista tutustua myös kunnan oman tilastotoimen aikaansaannoksiin. Luettelo keskeisimmistä selvittelytyössä tarvittavista tilastotauluista sisältyy 1 i itteeseen 2 esityksen lopussa.

Tledot kuntien väkiluvun kehityksestä niin kirkonkirjojen ja sivilirekisterin kuin henkikirjojen mukaan sisältyvät Suomen tilastolliseen vuosikirjaan. Väestönmuutosten lukumääräistiedot - syntyneet ja kuolleet, solmitut avioliitot sekä kuntaan ja kunnasta muuttaneet - taas sisältyvät Suomen virallisen tilaston (SVT) julkaisusarjaan VI A. Yksityiskohtaisemmat tiedot, esim. syntyneet äidin iän mukaan, lienevät parhaiten saatavissa tilastollisessa päätoimistossa säilytettävästä ensiaineistosta; kunnittaisinahan niitä ei julkaista. Mainittakoon, että päătoimisto on vuodesta 1951 lähtien koonnut otantamenetelmää käyttäen varsin perusteellisia tietoja muuttoliikkeestä. Näin ollen muuttaneiden ikä, sivililisääty, talouskuntakokoomus sekä saapumiskunta ja lähtökunta saadaan ehkä vafvattomimmin selvitetyksi kyseisestä lähteestä.

Väestön rakennetta - ikä-, sukupuoli- ja sivililisäätyjakautumaa sekä elinkeino- ja ammattiasemaryhmitystä - koskevat tiedot vuodelta 1950 saadaan väestölaskennassa valmistuneista julkaisemattomista kuntatauluista tilastollisesta päätoimistosta. Samoja seikkoja valaisevat väestörekisterien inventoinneissa laaditut ns. kymmenvuotistaulut aikaisemmilta 0 :an päättyviltä vuosilta - siis viimeksi vuodelta 1940 - ovat niinikään saatavissa tilastollisesta päätoimistosta. Kyseinen aineisto koskee kaikkia maamme kuntia. Vain suurimpia kaupunkejamme koskevat vuosina $1870-1930$ joka kymmenes vuosi suori tetut todelliset väestölaskennat, joiden tulokset on julkaistu SVT:n väestötilaston sarjassa VI. Paikkakunnan elinkeinoelämän tutkimuksessa ovat käyttökelpoisia lähteitä myös sellaiset tilastonalat kuin teollisuustilasto ja varsinkin liikeyrityslaskenta, jollainen meillä suoritettiin ensi kerran keväällä 1953, alkuaineistoineen.

Varsinaisissa tarvelaskelmissa vaadittavan talouskuntia ja a suntoja koskevan tilaston pääosa saadaan luonnollisesti väestölaskennasta. Huomattava on, että kaikki liitteessä mainitut taulut eivät suinkaan kuulu päätoimiston työohjelmaan, joten osa joudutaan käyttelyttämään erillistyönä. Vanhemmasta asunto-oloja selvittelevästä tilastosta on syytä kiinnittää huomiota erityisesti sosiaalisen tutkimustoimiston vuonna 1938 suorittamaan tutkimukseen, joka kohdistui 9 kaupunkiin, sekä suurimpien kaupunkiemme todellisten väestölaskentojen yhteydessä vuosina $1870-1930$ laadittuihin asunto-olojen selvityksiin. ${ }^{n}$

Asuntovajauksen eri termien arvioimisessa joudutaan turvautumaan huoneenvuokralautakunnan asunnonhakijatilastoon. Tällöin on kuitenkin muistettava ne rajoitukset, mitkä tällä aineistolla on. Sehän ei missään tapauksessa voi korvata asuntolaskennan tapaista totaalitutkimusta, mutta joi- 
denkin asunnontarvitsijaryhmien kuten alivuokralaisperheiden tai aivan kehnoissa asunnoissa asuvien talouksien lukumääristä se antanee jokseenkin luo. tettavan kuvan. - V a l m ist uneista samoin kuin puretuista a sunnoista saadaan tiedot paitsi kunnan rakennusviranomaisilta myös sosiaalisesta tutkimustoimistosta. Purettuja asuntoja koskevat tiedot lienevät yleensä tosin varsin puutteelliset. - Jo olemassa oleva tilastoaines el kuitenkaan ole täysin riittä?ă. Niinpä e ri ty isselvitykset ovat tarpeen. Tallaisia ovat jo aikaisemmin mainitut asunnontarkastuksen kehnojen asuntojen inventointi ja rakennustarkastajain laskelma asemakaavan toteuttamiseksi purettavista rakennuksista ja niiden asunnoista. Mikäli mahdollista, olisi myōs suoritettava tutkimus ulkokuntalaisten, mutta paikkakunnalla työssä käyvien henkilöiden asunnontarpeesta. Pienemmillä ja varsinkin sellaisilla paikkakunnilla, joissa on yksi koko elinkeinoelämää hallitseva suurteollisuuslaitos, selvityksen laatiminen käynee hyvin päinsä.

Lopuksi tähdennettäköön sitä, että laadittavan selvityksen dispositio, sisällys, voidaan luonnollisesti laajentaa käsittämään täydellisemmänkin väestö- ja asunto-olojen kuvauksen, kuin mikä yksinomaan tarvelaskelmien kannalta olisi tarpeen. Esimerkkeinä mainittakoon $\mathrm{mm}$. sellaiset kohteet kuin asuntojen mukavuudet ja hallintasuhde tai asumiskustannukset ja vuokranmaksukyky. Niin mielenkiintoinen kuin esim. viimeksi mainittu selvitys olisikin, joudutaan tilastonhankinnoissa vaikeuksiin, koska tätä kysymystä ei väestölaskennassa tutkittu. Mitä seikkaperäisempi paikkakunnallisesta selvityksestä halutaan — eikä siis tyydytä pelkkiin eri kokoisten asuntojen tarpeen laskelmiin —, sen väistämättömämmäksi muodostuu erityisen asuntolaskennan suorittaminen kunnassa.

Maaseutupaikkakunnan asunnontarpeen selvityksestä.

Kuten johdantoluvussa jo mainittiin, maaseudulla ja nimenomaan puhtaissa maatalouskunnissa asunnontarve on olemukseltaan siinä määrin toisenlainen kuin kaupungeissa tai kauppaloissa, että tähän eroavuuteen on myös esillä olevassa tehtävässä - paikkakunnallisen asunnontarpeen selvityksen hahmottelussa - syytä edes lyhyesti kiinnittää huomiota.

Väestökeskusten asuntopulmassa on viime sotien jälkeen ollut 
ja on yhä edelleen etualalla asuntojen $1 \mathrm{uk}$ u mä är äin en tarve. Sen sijaan maaseudulla - sodanjälkeisen valtavan asuttamisurakan lähetessä loppuaan - työntyvät etualalle nykyisen asuntokannan 1 a a d u 11 is et puutteet. ${ }^{28}$ Selvästi tämä seikka ilmenee esim. maaseudun asunto-olojen parantamiskomitean vuonna 1950 suorittamasta asuntotiedustelusta: asuntovajauksen laskettiin maalaiskunnissamme olevan noin 32000 , kun taas »uusimista, laajentamista tai korjaamista vaativissa asunnoissa elävien perheiden» luku nousi peräti 92 500:aan. ${ }^{29}$ Kun tarvitsijayksikköjen vuosittainen lisäys voidaan arvioida »vain» $4500: \mathrm{ksi}$, ei sekään aiheuta painopisteen siirtymistä kvalitatiiviselta kvantitatiiviselle puolelle.

On näin ollen selvää, että maaseutupaikkakunnan asunnontarpeen selvityksessä ei riitä pelkkä asuntovajauksen ja vuosittaisen lisätarpeen tutkiminen. Päähuomion tulee kohdistua a s u n t o je n la adulliseen tila an: moniko asunnoista on sellaisessa kunnossa, että se olisi rakennettava täysin uudestaan, monenko asunnon suhteen selvittäisiin pelkillä korjaamis- tai laajentamistoimenpiteillä sekä mitä suuruusluokkaa olevista rakennustehtävistä tällöin on kysymys. Näiden seikkojen selville saaminen on luonnollisesti varsin suuritöinen tehtävä, eikä sen vaatima tilastoaineisto liene hankittavissa muten kuin itse paikalla, toisin sanoen asunnoissa suoritettavan tiedustelun välityksellä.

Kyseisen selvityksen lähempään tarkasteluun ei tässä yhteydessä ole mahdollisuuksia. Sen sijaan esitettäköön joitakin maaseutupaikkakunnan asuntovajauksen ja lisätarpeen mitoittamiseen liittyviä huomautuksia.

Asuntovajauksen keskeisimmät ryhmät ovat, kuten väestökeskuksissakin, alivuokralaistaloudet sekä perheet, jotka asuvat samassa taloudessa toisen, esim. omaistensa perheen kanssa, mutta joiden on katsottava olevan oman asunnon tarpeessa. Viimeksi mainittujen tapausten suhteen on huomattava, että vaikka väestökeskuksissa moniperheisen talouden voidaankin sanoa säännönmukaisesti edustavan perheiden lukua vastaavaa asunnontarvetta, maaseudulla asian laita on hiukan toinen. Moniperheinen 
talouskunta ilmaisee näet siellä useinkin vain pysyvää asumistapaa, jonka välttämättömyyden sanelee yhteinen elinkeino, yhteisen maatilan hoito. Niinpä maaseudun asunto-olojen parantamiskomitean tiedustelussa todettuun asuntovajaukseen sisältyi arviolta $11000-12000$ toisen taloudessa elävää perhettä, mikä määrä on vain neljännes kaikista vastaavista tapauksista. Mitä asuntovajauksen muihin termeihin tulee, todettakoon vain, että asuntovarannon huomioon ottaminen maaseutukunnissa ei tietenkään ole tarpeen.

Lis ätarpeen arvioimisessa voitaneen menetellä samąan tapaan, kuin aikaisemmin tosin lähinnä väestökeskuksia silmällä pitäen kaavailtiin. Tehtävään ei siten ole aihetta pitemmälti kajota. On kuitenkin tähdennettävä, että elinkeinoelämän rakenteeseen ja jatkuvaan monipuolistumiseen kunnan alueella on syytä kiinnittää huomiota. Vaikka talouskuntia muodostavassa iässä olevan väestön määrä pysyisi ennallaan tai jopa laskisi, saattaa silti syntyä uusien asuntojen tarvetta. Näin on asian laita esim. silloin, kun maataloudesta siirtyy väkeä muiden elinkeinojen palvelukseen kunnan alueella. Talouskunnanmuodostuksen intensiteettihän on niissä tunnetusti voimakkaampi kuin maatalousväestön keskuudessa, mikä seikka on todettavissa mm. vertailtaessa väestökeskusten ja maaseudun talouskuntafrekvenssejä toisiinsa. ${ }^{30}$ Mikäli elinkeinoelämän differentioituminen on ehtinyt jo niin pitkälle, että kunnan alueelle on muodostunut kaupunkimaisia yhdyskuntia, t a a a mia, on asunnontarpeen selvityksessä syytä menetellä siten, että taajamat ja puhdas maaseutu tutkitaan molemmat erikseen, edelliset luonnollisesti siihen tapaan kuin muutkin väestökeskukset. Tilastotietojen hankkiminen tällaiseen kunnan. osien erillistarkasteluun kohtaa arvattavasti vaikeuksia, mutta ainakin vuoden 1950 väestölaskennassa taajamat ovat erotettavissa saman kunnan muusta aineistosta.

\section{Loppulause.}

Paikkakunnallisen asunnontarpeen selvitystä koskevan esityksemme tehtävänä on ollut hahmotella tutkimuksen yleinen raken- 
ne ja antaa joitakin viitteitä sen teknillistä suoritusta ja eräitä käytännöllisiä seikkoja kuten $\mathrm{mm}$. tilastomateriaalin hankintaa varten. Perustelemattakin on selvää, että selvityksen laatija joutuu todellisuudessa lukuisten sellaisten ongelmien eteen, joihin tästä esityksestä ei ole apua saatavissa. Tulevaisuuteen tähtäävissä laskelmissa varteen otettavat tekijäthän ovat mitä moninaisimmat vaihdellen paikkakunnasta toiseen. Siten esim. suuren kaupungin väestönkehityksestä, johon yhden - huomattavankaan - likelaitoksen perustaminen ei suuria vaikuta, voidaan otaksumat laatia jokseenkin varmalla pohjalla. Näin ei ole suinkaan asian laita pienellä paikkakunnalla, jossa tällaisen yrityksen ilmaantumisella voi olla suorastaan mullistavat seuraukset.

Vaikka asunnontarpeen selvityksen yleispiirteet ovatkin hahmoteltavissa, ei näin ollen mitään standardiohjeita sen pienimpiäkin y ksityiskohtia myöten voida antaa. Siten tutkimuksen laatijalle asetettavat vaatimukset kasvavat. Paitsi tilastolliseen metodiin ja lähdeaineistoon hänen tulee olla perehtynyt paikkakunnan oloihin ja erikoispiirteisiin. Viimeksi mainituissa suhteissa puutteet ovat tosin korvattavissa, mikäli kunnan viranomaisten ja muidenkin henkilöiden edustama paikallinen asiantuntemus on tutkijan helposti tavoitettavissa ja käytettävissä.

Paikkakunnallisen asunnontarpeen selvityksen suuri merkitys sekä varsinaiselle asuntopolitiikalle että kunnan kehittämiseen tähtäävälle suunnittelulle yleensäkin ei liene kiistettävissä. Toistaiseksi ei maassamme tällaisia tutkimuksia asuntoprognooseineen kuitenkaan liene suoritettu joitakin aivan yleisluontoisia laskelmia lukuunottamatta. Ruotsissa niitä sen sijaan on viime kymmenen vuoden aikana laadittu varsin runsaasti; velvoittaapa vuonna 1947 annettu lakikin jokaisen kunnan, jossa on vähintään 10000 asukasta - joissakin tapauksissa pienemmänkin - laatimaan yksityiskohtaisen tarvetutkimukseen perustuvan asunnontuotanitosuunnitelman noin 10 vuodeksi kerrallaan. Asuntohallituksen suunnittelutoimiston tulee taas puolestaan antaa apuaan näiden paikallisselvitysten laatimisessa.

Millaisiksi asuntopoliittisen tutkimuksen ja suunnittelun ulko- 
naiset muodot maassamme kehittyvätkin, tässä kirjoituksessa esitetty johdatus paikkakunnallisen asunnontarpeen selvitykseen on saavuttanut tarkoituksensa, mikäli se osaltaan voi auttaa pyrkimyksiä entistä kiinteämpään ja varmemmalla pohjalla olevaan toimintaan asunto-olojemme parantamiseksi.

\section{Lähdeviitteitä ja huomautuksia.}

1. Kaupunkien ja kauppalain asunnontarve. Väestöpoliittinen tutkimuslaitos. (Jouluk. 1952, moniste, 21 s). - Maaseudun asunnontarve. Väestöpoliittinen tu:kimuslaitos. (Helmik. 1953, moniste, 22 s.). - Strömmer, Aarno, Väestökeskusten ja maaseudun asunnontarve. Sosiaalinen Aikakauskirja 1953, ss. $89-104$.

2 Niistä mainittakoon erityisesti seuraavat: Slutbetänkande avgivet av Bostadssociala utredningen. Del I. SOU 1945: 63. Tukholma. Ss. 297-327 (befolkningsutvecklingen och bostadsbehov âren $1940-60$ ). - Sandviken planerar sin bostadsförsörjning. En undersökning av stadens befolkningsutveckling, bostadsförhâllanden och framtida bostadsbehov àren $1940-60$. Pả uppdrag av Sandvikens stads bostadskommitté utförd av Svenska Riksbyggen. Gävle 1945. -- Forbat, Fred, Utvecklingprognos för en medelstor stad. En studie över näringsliv, befolkning och bostäder i Skövde. Statens kommitté för byggnadsforskning. Rapporter. Nr. 18. Tukholma 1949. - Generalplan för Eskilstuna. Enligt generalplaneberedningens uppdrag utarbetad på stadsarktitektkontoret i Eskilstuna 1943-1947. Eskilstuna 1950. - Generalplan for Falköping. Upprättad åren 1946-1951 av Eglers stadsplanebyrá. Falköping ro51.

3 Tamminen, Mikko, Suomen kaupunkien asuntotuotannon vaihtelut ja nilden syyt itsenäisyyden aikana. Suomen Pankin taloustieteellisen tutkimuslaitoksen julkaisuja. Sarja B: 4. Helsinki 1945. S. 33.

- Tässä yhteydessä lienee syytä mäăritellä eräitä asunnontarvetutkimuksen peruskäsitteitä: A s unnolla eli asuinhuoneistolla tarkoitetaan huonetta tai huoneryhmää, joka on rakennusteknillisesti muista huoneistoista erotettu ja varustettu omalla sisäänkäytävalllä suoraan ulkoa tai porraskäytävästā ja jota käytetään pääasiallisesti asumiseen. (Vrt. Modeen, G., Asunnontarve asutuskeskuksissa, Sosiaalinen Aikakauskirja 1947, s. 97; Block, Alexander, Estimating Housing Needs, Glasgow 1946, ss. 16-1'7.) Huomattakoon lisäksi, ettā asuntokàsitteen ulkopuolelle jätetään tässä esityksessä ns. laitosasunnot. T a 1ouskunnalla eli ruokakunnalla tarkoitetaan kokonaisuutta, jonka muodostavat perheenjäsenet ja muut henkilöt, jotka asuvat yhdessä ja joilla on yhteinen ruokatalous. Tavallisesti se käsittää vain perheen (vanhemmat ja lapset), mutta mikäli perheellä on talousapulainen, kuuluu hänkin samaan talouskuntaan. Sen sijaan samassa huoneistossa asuva alivuokralainen muodostaa oman talouskuntansa. Kaikkia samassa asunnossa eläviä henkilöitä nimitetään a s u in ta 1 oudeksi. Jälleen huomautettakoon, että käsite talouskunta ei sisällä ns. laitostalouksia.

s Asuntovarannolla eli asuntoreservillä tarkoitetaan "sitā suurem. paa tai pienempää vuokraamattomien asuntojen määräă, joka sāännöllisisssả oloissa esiintyy vuokramarkkinoilla". Tamminen, m.t., s. 133. Asuntopoliittisessa. 
kjrjallisuudessa pidetään yleensä sopivana - asunnontarvitsijoiden kitkattoman muuttovapauden takaavana - varantona määrää, joka käsittää $2-3 \%$ koko asuntokannasta.

- Selvää on, että seurauksena vallitsevan asuntovajauksen poistamisesta joukko taulukon esittämistä asuntotalouksista "hajoaisi" kahteen, ehkä useampaankin asunnontarvitsijayksikköön. Näin ollen "normaalin" asuntotilanteen vallitessa asuntotalouksia olisi useampia, ja ne olisivat keskimääräiseltä kooltaan pienempiä kuin nyt. Vastaavasti olisi ahtaasti asumisen määrä ja samalla ero todellisen ja optimiasuntokannan välillä nykyistä jossain määrin vähäisempi. Ratkaisevasti vertailun antama kuva ei kuitenkaan muuttuisi.

7 Tamminen, m.t., s. 86.

- Tamminen, m.t., s. 60 .

- Asunnottomien ja alivuokralaistalouksien oman, erillisen asunnon tarpeen "tärkeyttä" ajateltaessa voidaan kyseiset talouskunnat jakaa vielä perheisỉn ja yksinäisiin henkilöihin. Väestölaskennan ennakkotietojen mukaan oli koko ryhmän suuruus kaupungeissa ja kauppaloissa 69800 talouskuntaa, joista perheitä (kahden tai useamman hengen talouksia) $18400(26 \%)$ ja yksinäisiä henkilöitä $51400(74 \%)$. Missä määrin viimeksi mainitun luvun tarkoittamat, jo py_ syvästi (se ei siis sisällä esim. opiskelija-alivuokralaisia) itsenäisiksi "yksiköiksi" irtautuneet yksinäiset henkilöt on katsottava oman erillisen asunnon tarpeessa oleviksi, on kysymys sinänsä, johon varsinaisissa asunnontarpeen selvityksissä ei tarvinne ottaa kantaa. Riittänee, kun osoitetaan yksinäisten henkilöiden osuus (ja mahdollisesti heidän ikäjakautumansa) kaikista esillä olevan ryhmän talouksista. Kuriositeettina mainittakoon, että Helsingin kaupungin tilastotoimiston suorittamassa asuntavajauslaskelmassa vuodenvaihteessa $1950 / 51$ (Tilastollisia kuukausitietoja Helsingistä 11,1951 , ss. 191-192) otettiin vain $25 \%$ yksinäisistä alivuokralaisista mukaan arvioon.

10 Mikäli halutaan olla tarkkoja, olisi otettava huomioon myös asuntojen jakamisesta, yhdistämisestä ja muuhun käyttöön siirtämisestä aiheutuvat asuntokannan muutokset. Tietoja näistä seikoista on saatavissa huoneenvuokralautakunnilta, joiden lupa ainakin toistaiseksi vaaditaan kyseisiin toimenpiteisiin.

1I Todettakoon, että viitteessä 9 mainitussa Helsingin tutkimuksessa irtautumistarve usean perheen talouskunnista arvioitiin otaksuen, että $20 \%$, talouskunnista, joissa on vähintään 4 yli 15 -vuotiasta henkilöä, eđustaa uuden asunnon tarvetta.

12 Tampereen seutusuunnitteluliitto toimeenpani tällaisen tiedustelun Tampereella työssä käyvien työntekijäin asuinkuntaa ja työmatkaa koskevan selvityksen yhteydessä toukokuussa 1953. Tiedustelulomake jaettiin ja koottiin samaan aikaan suoritetun liikeyrityslaskennan koneiston välityksellä.

1 Mielenkiintoisena vertailuna voidaan mainita, että Sandvikenissä vuonna 1945 (ks. viitettä 2) suoritetussa asunnontarpeen selvityksessä (s, 41) asunnontarkastus totesi tässä Lappeenrannan kokoisessa kaupungissa olevan 244 "välittömästi tyhjennettävää asuntoa". Niistä oli 1-huoneisia 140, 2-huoneisia 88 sekä 3-huoneisia ja sitä suurempia 16. Lisäksi "hyvin puutteellisia asuntoja, jotka tulisi tyhjentää ennen vuotta 1955", oli 274.

I4 Väestökeskusten osalta luvut perustuvat väestölaskennan aineistosta laadittuun otantatutkimukseen (ks. Strömmer, m.k., ss. 89 ja 97), kun taas Lappeenrannan ja Paraisten luvut on saatu käyttelyttämällä näiden paikkakuntien koko aineisto.

1s Talouskunnanmuodostukseen vaikuttavien tekijöiden suhteen ks. esim.: Bostäder och hushảll. Enligt allmänna bostadsräkningen 1945 och därtill anslutna 
undersökningar av Kungl. Socialstyrelsen. Sveriges officiella statistik. Tukholma 1952. Ss. $126-128$.

16 Erinomaisen esimerkin paikkakunnan elinkeinoelämän "absorbointikyvyn" tunnontarkasta analysoinnista tarjoaa Fred Forbat'in Skövden tutkimus (ks. viitettä 2). Kovin yksityiskohtaisen ja suuritöisen pohjatutkimuksen tarkoituksenmukaisuutta on ,kuitenkin syytä epäillä. Ks. esim. kirjoitusta: Näringslivets förändringar inom kommunen och befolkningsprognoser. Planläggning 1 landiskommun Upsala 1953. Ss. 16-21.

17 Malmön äskettäin valmistuneessa asuntoprognoosissa on yleisestä käytännöstä poiketen otettu huomioon myös vallitsevan asuntopulan aiheuttama avioitumisen viivästyminen: naimisissa olevien osuuden nuorissa ikäluokissa (20 -35 v.) on nimittäin oletettu suhteellisen nopeasti kohoavan sille tasolle, jolla se nyt olisi ilman asuntopulaa. Laskelman perustana ovat tiedot asunnonvälitykseen ilmoittautuneista avioliittoon aikovista pareista. Ks. Lindman, Gunnar, Ett nytt försök till bostadsbehovsprognos. Att bo 1, 1953.

is Vuosina 1948-49 laaditussa Helsingin väestöprognoosissa vuoteen 1980 saakka laskelmat suoritettiin syntyneisyysluvun (syntyneitä vãestön 1000 hen. kilöä kohden) kolmen vaihtoehdon mukaan: $12 \%$, $15 \%$ ja $18 \%$. Syntyneistä $51.4 \%$ oletettiin pojiksı. Ks. Tilastollisia kuukausitietoja Helsingistä 2, 1950. S. 17 .

19 Talouskunnan asemesta on Ruotsin laskelmissa käytetty laajempaa käsitettä "asuntotalous"; alivuokralaistalouskuntia ef toisin sanoen ole kàsitelty erillisinä yksikköinä. Ero talouskuntafrekvensseissä ja asuntotalousfrekvensseissä ilmeneekin lähinnä naimattomien henkilöiden kohdalla. Helsingin talouskunta- ja asuntotalousfrekvensseistä vuonna 1950 on mielenkiintoinen vertallu Tilastollisissa kuukausitiedoissa Helsingistä $3,1953$.

so Ks. myös Tammisen esitystä rakennuskannan uusimisen ja ns. keskustan sirtymisen vaikutuksesta asunnontarpeeseen. M.t., ss. $74-78$.

21 Forbat, Fred, m.t., s. 65. Ole Gripenberg on laskenut Suomen koko rakennuskannan vuosittaisen "uutisoimistarpeen" olevan $1.24 \%$. Luku koskee kuitenkin kaikkia rakennuksia, myös maatalous-, teollisuus- ja likerakennuksia, joiden käyttöikä on huomattavasti lyhyempi kuin asuinrakennusten. Sen vuoksi ko. luku on asuntokantaan sovellettuna aivan lilan suuri. Ks. Gripenberg, Ole, Miten suuri on maamme rakennustarve. Rakennustaito 2, 1953.

z2 Lindman, m.k., ss. 16-17.

2s Sandviken planerar sin bostadsförsörjning, s. 67.

24 Generalplan för Eskilstuna, ss. 77-78.

25 Sama, ss. $82-83$.

26 SOU 1945: 63 , ss. $316-317$.

$n$ Ks. myös selontekoa maamme asuntotilastollisesta aineksesta tämän kirjan ss. $7-24$.

s8 Vrt. esim. kirjoitusta Det framtida bostadsbehovet och planeringen av bostadsförsörjningen. Plannläggning 1 landskommun. Upsala 1953. Ss. 22-26.

sง Maaseudun asunto-olojen parantamiskomitean mietintō. Komiteanmietintō 9, 1951. Helsinki. Ss. 36-41.

so Ks. Strömmer, m.k., s. 97. 
Liite 1. Eloonjäämistodennäköisyys eri ikäluokissa eli 1 000:sta edelliseen viisivuotisryhmään kuuluvasta viiden vuoden kuluttua keskimäärin elossa olevat $1951-55$... 1966-70. *

\begin{tabular}{|c|c|c|c|c|}
\hline Ikäryhmä & $1951-55$ & $1956-60$ & $1961-65$ & $1966-70$ \\
\hline $0-4^{* *}$ & 930.8 & $\begin{array}{r}\text { Miehet } \\
936.0\end{array}$ & 941.2 & 946.4 \\
\hline $5-9$ & 976.5 & 978.6 & 9807 & 9828 \\
\hline $10-14$ & 988.6 & 989.5 & 990.4 & 991.3 \\
\hline $15-19$ & 986.1 & 987.2 & 988.3 & 989.4 \\
\hline $20-24$ & 9728 & 973.7 & 9746 & 9755 \\
\hline $25-29$ & 971.1 & 9720 & 972.9 & 9738 \\
\hline $30-34$ & 971.6 & 972.5 & 973.4 & 974.3 \\
\hline $35-39$ & 9683 & 969.2 & 970.1 & 971.0 \\
\hline $40-44$ & 962.9 & 964.0 & 965.1 & 966.2 \\
\hline $45-49$ & 948.1 & 949.2 & 950.3 & 951.4 \\
\hline $50-54$ & 930.9 & 932.7 & 934.5 & 936.3 \\
\hline $55-59$ & 900.3 & 901.9 & 903.5 & 9051 \\
\hline $60-64$ & 858.4 & 860.3 & 862.2 & 864.1 \\
\hline $65-69$ & 802.5 & 805.2 & 8079 & 8106 \\
\hline $70-74$ & 731.6 & 736.9 & 742.2 & 747.5 \\
\hline $75-79$ & 636.5 & 645.5 & 654.5 & 6635 \\
\hline $80-84$ & 506.3 & 509.4 & 5125 & 515.7 \\
\hline $85-89$ & 357.0 & 3580 & 359.0 & 3599 \\
\hline $90-94$ & 183.9 & 185.7 & 187.6 & 189.5 \\
\hline $95-99$ & 59.3 & $\begin{array}{c}59.3 \\
\text { Naiset }\end{array}$ & 59.3 & 59.3 \\
\hline $0-4^{* *}$ & 943,0 & 948.0 & 953.0 & 9580 \\
\hline $5-9$ & 979.1 & $98: 1$ & 983.1 & 985.1 \\
\hline $10-14$ & 9908 & 991.6 & 992.4 & 9932 \\
\hline $15-19$ & 9880 & 9890 & 990.0 & 991.0 \\
\hline $20-24$ & 981.7 & 9826 & 9835 & 984.4 \\
\hline $25-29$ & 979.6 & 980.8 & 982.0 & 983.2 \\
\hline $30-34$ & 9793 & 980.5 & 981.7 & 982.9 \\
\hline $35-39$ & 979.4 & 980.6 & 981.8 & 983.0 \\
\hline $40-44$ & 977.7 & 979.0 & 980.3 & 981.6 \\
\hline $45-49$ & 973.2 & 9748 & 976.4 & 9780 \\
\hline $50-54$ & 967.3 & 969.6 & 971.9 & 974.2 \\
\hline $55-59$ & 950.8 & 952.5 & 954.2 & 955.9 \\
\hline $60-64$ & 926.8 & 929.7 & 932.6 & 935.5 \\
\hline $65-69$ & 8862 & 891.0 & 895.8 & 900.6 \\
\hline $70-74$ & 8151 & 821.6 & 828.1 & 8346 \\
\hline $75-79$ & 707.0 & 715.5 & 724.0 & 7325 \\
\hline $80-84$ & 566.0 & 5759 & 585.8 & 5957 \\
\hline $85-89$ & 400.2 & 406.8 & 413.5 & 420.1 \\
\hline $90-94$ & 233.5 & 235.2 & 236.9 & 238.7 \\
\hline $95-99$ & 909 & 90.9 & 90.9 & 90.9 \\
\hline
\end{tabular}

- Lifltyy esitykseen s. 108. Lähde: Jorma Hyppölä-Aarre Tunkelo-Leo Törnqvist, Suomen väestöă, sen uusiutumista ja tulevaa kehitystä koskevia laskeimia. Tilastollisia tiedonantoja (julkaissut tilastollinen päätoimisto) 38. Helsinki 1949. Ss. $124-125$ (taulu 12, otaksuma 3 ). 
Paikkakunnallisen asunnontarpeen selvityksessä tarvittavat tilastotaulut.

A. Väestötiedot.

Suomen tilastollinen vuosikirja:

1. Väkiluku kirkonkirjojen ja sivililirekisterin sekä henkikirjojen mukaan ..., 1949, 1950, 1951, ...

Väestönmuutostilasto (SVT VI A):

2. Syntyneet $\ldots, 1949,1950,1951, \ldots$

3. Kuolleet, samoilta vuosilta.

4. Solmitut avioliitot, samoilta vuosilta.

5. Kuntaan ja kunnasta muuttaneet, samoilta vuosilta.

Tilastollisessa päätoimistossa oleva julkaisematon aineisto:

6. Kuntaan ja kunnasta muuttaneet iän, sukupuolen ja sivilisäädyn mukaan 1951- ...

7. Kuntaan ja kunnasta muuttaneet 1951 - ... talouskunnan suuruuden mukaan.

8. Kuntaan ja kunnasta muuttaneet $1951-\ldots$ sen paikkakunnan mukaan, josta tai jonne muutto on tapahtunut.

9. Väestö iän, sukupuolen ja sivililisäädyn mukaan ...., 1940, 1950.

10. Väestö elinkeinon ja ammattiaseman mukaan ..., 1940, 1950.

B. Talouskunta-ja asuntotiedot.

Vuoden 1950 väestölaskennan aineisto tilastollisessa päätoimistossa:

11. Talouskunnat henkilolluvun mukaan.

12. Talouskunnat nilhin kuuluvien perheiden luvun mukaan.

13. Talouskunnan päämiehet iän, sukupuolen ja sivililisäädyn mukaan.

14. Sama, asunnonhaltijat.

15. Sama, alivuokralaistalouksien paämiehet.

16. Sama, yksinäiset alivuokralaiset.

17. Talouskunnat henkilöluvun ja huoneiden lukumäärän mukaan.

18. Sama, alivuokralaistaloudet.

19. Asuinhuoneistot huoneiden lukumäärän ja henkilöluvun mukaan.

20. Asuinrakennukset iän, rakennusaineen ja eri suuruisten asuntojen lukumäärän mukaan.

Huoneenvuokralautakunnan asunnonhakijakortisto:

21. Paikkakunnalla asuvat asunnonhakijat ryhmiteltynă päävuokralais- ja muihin talouksiin henkilōluvun mukaan. 
22. Paikkakunnan ulkopuolella asuvat hakijataloudet ryhmiteltynä henkilöluvun mukaan.

23. Paikkakunnalla asuvat päävuokralaistaloudet ryhmiteltynä asunnontarpeen ensisijaisen syyn mukaan.

24. Samassa taloudessa toisen - esim. omaistensa - perheen kanssa asuvat hakijaperheet henkilöluvun ja perheen päämiehen iän mukaan.

Kunnan rakennusviranomaisten asunnontuotantotilasto:

25. Valmistuneet asunnot huoneluvun mukaan ..., 1949, 1950, $1951, \ldots$

26. Puretut asunnot huoneluvun mukaan, samalta ajalta.

Erityisselvitykset:

27. Asunnot, jotka terveydellisistä tai asemakaavallisista syistä tulisi välittömästi poistaa käytöstä, huoneiden lukumäärän ja henkilöluvun mukaan.

28. Ulkokunnissa asuvat taloudet, joiden päämies käy työssä tutkittavassa kunnassa ja jotka ovat siellä oman asunnon tarpeessa, henkilöluvun mukaan. 